\title{
Effect of Organic and Inorganic Fertilizers on Seed Quality of Different Varieties of Chilli (Capsicum annum L.)
}

\section{Amit Mishra* and Abhinav Dayal}

Department of Genetics and Plant Breeding, Sam Higginbottom University of Agriculture, Technology and Sciences, Allahabad, Uttar Pradesh, India

*Corresponding author: Mishra A, Department of Genetics and Plant Breeding, Sam Higginbottom University of Agriculture, Technology and Sciences, Allahabad, Uttar Pradesh, India, Tel: 0532268 4781; E-mail: amit.bhira2011@hotmail.com

Received: May 21, 2018; Accepted: May 31, 2018; Published: June 05, 2018

Copyright: () 2018 Mishra A, et al. This is an open-access article distributed under the terms of the Creative Commons Attribution License, which permits unrestricted use, distribution, and reproduction in any medium, provided the original author and source are credited.

\begin{abstract}
The present investigation was conducted during Kharif 2017-2018 at the Field Experimentation Centre of the Department of Genetics and Plant Breeding, Sam Higginbottom University of Agriculture, Technology and Sciences (U.P), during the year of 2017-2018. The experiment was conducted in field and laboratory to evaluate of organic and inorganic fertilizer on mother plant. The experimental trial consists of 8 treatment combinations comprising of 2 different varieties of chilli carried out in Randomized Block Design (factorial). The chilli varieties used were Suryamukhi and Chilli G-4. The treatments included $\mathrm{T}_{0}=$ control, $\mathrm{T}_{1}=$ Urea RDN, $\mathrm{T}_{2}=100 \%$ Vermicompost, $\mathrm{T}_{3}=50 \%$ Urea and $50 \%$ Vermicompost, $\mathrm{T}_{4}=100 \% \mathrm{FYM}, \mathrm{T}_{5}=50 \%$ Urea and $50 \% \mathrm{FYM}, \mathrm{T}_{6}=50 \%$ Vermicompost and $50 \% \mathrm{FYM}$ and $\mathrm{T}_{7}=50 \%$ Urea, $50 \%$ Vermicompost and $50 \% \mathrm{FYM}$. All the 9 seed quality parameters treated with $\mathrm{T}_{7}$ recorded higher are germination per cent $(99 \%)$, root length $(2.37 \mathrm{~cm})$, shoot length $(3.06 \mathrm{~cm})$, seedling length $(5.37 \mathrm{~cm})$, seedling dry weight $(0.036 \mathrm{mg})$, vigour index I (531.95), vigour index II (3.60), speed of germination (2.155), germination energy (2.940), and lower electrical conductivity (1.116). The application of treatment with $\mathrm{T}_{7}(50 \%$ Urea, $50 \%$ Vermicompost and 50\% FYM) dose in mother plant. All the fertilizer treatment except chemical fertilizer shows better performance in all the characters. The variety G-4 performed better than Suryamukhi.
\end{abstract}

Keywords: Urea; Vermicompost; FYM; Seed quality

\section{Introduction}

Chilli is an important crop used as both green vegetable and spices. It's rich source of vitamin $\mathrm{A}, \mathrm{C}$ and $\mathrm{E}$. The pungency in chilli is due to an alkaloid capsaicin. This has high medicinal value especially anticancerous and instant pain relief. In India major chilli growing states are Andhra Pradesh, Karnataka, Maharashtra, West Bengal, Rajasthan, etc. With the indiscriminate use of fertilizers and chemicals there is increased risk of health hazards. Since, vegetables are mostly consumed fresh or partially cooked they should be devoid of residues of chemical fertilizers. Besides, continuous use of chemical fertilizers has resulted in the depletion of soil health. For all these reasons, now much importance is being given to Integrated Nutrient Management (INM). Chilli crop respond well to the application of both organic manures and inorganic fertilizers. Organic manures supply the major nutrients minerals and improve many soil properties and soil health that maintain crop productivity [1].

Organic agriculture is one among the longest spectrum in production methods that are supportive of the environment. Application of inorganic fertilizer to agriculture is now common practice, using composts derived from various green wastes in agriculture is tardily coming back. Compost contains variable amounts of $\mathrm{N}, \mathrm{P}$ and $\mathrm{K}$ and it is a valuable source of plant nutrients. Cost of inorganic fertilizers is very high and sometimes it is not available in the market right time it leads to the farmers fail to apply the inorganic fertilizers to the crop field in optimum time [2].

On the other hand, the organic manure is easily available to the farmers and its cost is low compared to that of inorganic fertilizers. Most often this new type of technology (organic agriculture) is defined as a system for maintenance of the natural fertility of the soil, biological diversity of the species and the ecological balance of the environment. Application of vermicompost produced by biodegradable waste could be one of the most economical and attractive methods of solving the problems like waste disposal and the requirement to increase the organic matter content of soil. In the present study soil analysis was done prior to the experiment to determine the availability of nutrients in the soil and also to calculate the equivalent amount of organic or chemical fertilizer requirement of soil nutrients [2].

Most small-scale farmers still rely on crude inputs, land and human labour with less use of chemical fertilizers and improved varieties of crops. The use of fertilizer is reported to be responsible for over 50 percent yield increase in crops. It has been widely accepted that organic farming alone could serve as a holistic approach towards achieving sustainable agriculture as it is nature based, environment friendly and ensures the conservation of resources for the future. These chilli's are potentially valuable niche crops for small scale and medium farmers [1].

\section{Materials and Methods}

The experiment was carried out in Laboratory of Department of Genetics and Plant Breeding (Naini Agricultural Institute), Sam Higginbottom University of Agriculture, Technology and Sciences Allahabad (U.P). To find out the effect of organic and inorganic fertilizers on seed quality and yield of different varieties of chilli (Capsicum annum L.). The experiments were conducted in a Complete Randomized Design (factorial) with four replication having eight treatments combined and individual involving chemical and organic manures along with no manure control. The different chemical and organic manure treatments tried were $\mathrm{T}_{0}$ Control, $\mathrm{T}_{1}$-Urea $\mathrm{RDN}, \mathrm{T}_{2}$ - 
Vermicompost (2.5 $\left.\mathrm{tha}^{-1}\right), \mathrm{T}_{3}-50 \%$ Urea 100 and 50\% Vermicompost $\mathrm{T}_{4}$-FYM (2.5 $\left.\mathrm{t} \mathrm{ha}^{-1}\right), \mathrm{T}_{5}-50 \%$ Urea and 50\% FYM, T6-50\% FYM and $50 \%$ Vermicompost, $\mathrm{T}_{7}-50 \%$ Urea, 50\% Vermicompost and 50\% FYM. The experiment was done in top of paper method in four replications. The observation are on germination percent $(\%)$, root length $(\mathrm{cm})$, shoot length $(\mathrm{cm})$, seedling length $(\mathrm{cm})$, seedling dry weight $(\mathrm{mg})$, vigour index (I and II), speed of germination, germination energy, electrical conductivity $\left(\mathrm{dsm}^{-1}\right)$.

\section{Results}

The results provided in the table indicate the significant effect of organic manures on the seed quality and yield of chilli under various parameters.

\section{Germination percent (\%)}

Among the treatments significantly higher germination was recorded in variety G-4 with treatment $\left(\mathrm{T}_{7}\right) \quad 50 \%$ Urea, $50 \%$ Vermicompost and 50\% FYM. The germination was recorded in $T_{7}$ (99\%) followed by treatment $\mathrm{T}_{6}(98 \%)$ in combined given treatment. In individual given treatments the higher germination were recorded in
$\mathrm{T}_{2}$ (96\%). The lowest germination was recorded in $\mathrm{T}_{1}(91 \%)$. In variety Suryamukhi the higher germination was recorded with treatment $\left(\mathrm{T}_{7}\right)$ $50 \%$ Urea, 50\% Vermicompost and 50\% FYM. The germination was recorded in $\mathrm{T}_{7}$ (95\%) followed by treatment $\mathrm{T}_{4}(86 \%)$ in combined given treatment. In individual given treatments the higher germination were recorded in $\mathrm{T}_{2}(93 \%)$. The lowest germination was recorded in $\mathrm{T}_{1}$ (85\%) [3].

\section{Root length (cm)}

Among the treatments significantly higher root length was recorded in variety G-4 with treatment $\left(\mathrm{T}_{7}\right) 50 \%$ Urea, $50 \%$ Vermicompost and $50 \%$ FYM. The higher root length was recorded in $\mathrm{T}_{7}(2.4 \mathrm{~cm})$ followed by treatment $\mathrm{T}_{5}(2.4 \mathrm{~cm})$ in combined given treatment. In individual given treatments the higher root length was recorded in $\mathrm{T}_{2}(2.02 \mathrm{~cm})$ (Table 1). The lowest root length was recorded in $\mathrm{T}_{0}(1.52 \mathrm{~cm})$. In variety Suryamukhi the higher root length was recorded with treatment $\left(\mathrm{T}_{7}\right)$ 50\% Urea, 50\% Vermicompost and 50\% FYM. The root length was recorded in $\mathrm{T}_{7}(2.35 \mathrm{~cm})$ followed by treatment $\mathrm{T}_{6}(1.95$ $\mathrm{cm})$ in combined given treatment. In individual given treatments the higher root length was recorded in $\mathrm{T}_{2}(1.92 \mathrm{~cm})$. The lowest root length was recorded in $\mathrm{T}_{1}(1.47 \mathrm{~cm})[4]$.

\begin{tabular}{|c|c|c|c|c|c|c|c|c|c|c|c|c|c|c|c|}
\hline \multirow[t]{2}{*}{ Treatment } & \multicolumn{3}{|c|}{ Germination \% } & \multicolumn{3}{|c|}{$\begin{array}{l}\text { Root Length } \\
\text { (cm) }\end{array}$} & \multicolumn{3}{|c|}{$\begin{array}{l}\text { Shoot Length } \\
\text { (cm) }\end{array}$} & \multicolumn{3}{|c|}{$\begin{array}{l}\text { Seedling Length } \\
(\mathrm{cm})\end{array}$} & \multicolumn{3}{|c|}{$\begin{array}{l}\text { Seedling Dry Weight } \\
(\mathrm{mg})\end{array}$} \\
\hline & V1 & V2 & Mean & v1 & V2 & Mean & V1 & V2 & Mean & V1 & V2 & Mean & V1 & V2 & Mean \\
\hline $\mathbf{T}_{0}$ & 87.00 & 92.00 & 89.50 & 1.47 & 1.52 & 1.50 & 2.15 & 2.27 & 2.21 & 3.72 & 3.95 & 3.85 & 0.017 & 0.012 & 0.015 \\
\hline$T_{1}$ & 85.00 & 91.00 & 88.00 & 1.65 & 1.82 & 1.73 & 2.17 & 2.40 & 2.28 & 4.15 & 3.15 & 4.15 & 0.022 & 0.027 & 0.025 \\
\hline $\mathbf{T}_{2}$ & 93.00 & 96.00 & 94.50 & 1.92 & 2.02 & 1.97 & 2.30 & 2.25 & 2.27 & 4.30 & 4.32 & 4.31 & 0.030 & 0.030 & 0.030 \\
\hline $\mathbf{T}_{3}$ & 91.00 & 98.00 & 94.50 & 1.87 & 1.97 & 1.92 & 2.25 & 2.47 & 2.36 & 4.27 & 4.45 & 4.36 & 0.017 & 0.030 & 0.024 \\
\hline $\mathrm{T}_{4}$ & 86.00 & 93.00 & 89.50 & 1.67 & 1.77 & 1.72 & 2.22 & 2.52 & 2.37 & 4.17 & 4.22 & 4.20 & 0.030 & 0.020 & 0.025 \\
\hline $\mathbf{T}_{5}$ & 92.00 & 94.00 & 93.00 & 1.95 & 2.40 & 2.17 & 2.40 & 2.55 & 2.47 & 4.32 & 4.50 & 4.41 & 0.030 & 0.030 & 0.030 \\
\hline $\mathbf{T}_{6}$ & 95.00 & 98.00 & 96.50 & 1.95 & 2.32 & 2.13 & 2.42 & 2.80 & 2.61 & 4.45 & 4.60 & 4.52 & 0.020 & 0.027 & 0.024 \\
\hline $\mathbf{T}_{7}$ & 99.00 & 99.00 & 99.00 & 2.35 & 2.40 & 2.37 & 3.00 & 3.12 & 3.060 & 5.30 & 5.45 & 5.37 & 0.035 & 0.037 & 0.036 \\
\hline Mean & 91.00 & 95.12 & 93.06 & 1.85 & 2.03 & 1.94 & 2.36 & 2.55 & 2.45 & 4.33 & 4.45 & 4.39 & 0.025 & 0.027 & 0.026 \\
\hline $\begin{array}{l}\text { For comparing } \\
\text { the means of }\end{array}$ & \multicolumn{2}{|c|}{ SE.m \pm} & $C D$ at $5 \%$ & \multicolumn{3}{|c|}{ SE.m \pm} & \multicolumn{3}{|c|}{ SE.m \pm} & SE.m \pm & \multicolumn{2}{|c|}{ CD at $5 \%$} & \multicolumn{2}{|c|}{ SE.m \pm} & CD at $5 \%$ \\
\hline Variety (V) & \multicolumn{2}{|l|}{0.554} & 1.114 & 0.043 & & 86 & 0.050 & 0.1 & & 0.045 & 0.0 & & 0.000 & & \\
\hline Treatment ( $\mathrm{T})$ & 1.108 & & 2.229 & 0.086 & & 73 & 0.100 & & & 0.090 & 0.1 & & 0.001 & & \\
\hline$V \times T$ & 1.567 & & 3.152 & 0.122 & & 45 & 0.142 & 0.2 & & 0.128 & 0.2 & & 0.002 & & \\
\hline
\end{tabular}

Table 1: Effect of organic and inorganic fertilizer on germination, root length, shoot length, seedling length, seed dry weight on number of branches at different stages of chilli (Capsicum annum L.).

\section{Shoot length $(\mathrm{cm})$}

Among the treatments significantly higher shoot length was recorded in variety G-4 with treatment $\left(\mathrm{T}_{7}\right) \quad 50 \%$ Urea, $50 \%$ Vermicompost and 50\% FYM. The shoot length was recorded in $\mathrm{T}_{7}$ $(3.12 \mathrm{~cm})$ followed by treatment $\mathrm{T}_{6}(2.80 \mathrm{~cm})$ in combined given treatment. In individual given treatments the higher shoot length was recorded in $\mathrm{T}_{4}(2.52 \mathrm{~cm})$. The lowest shoot length was recorded in $\mathrm{T}_{2}$ $(2.25 \mathrm{~cm})$. In variety Suryamukhi the higher shoot length was recorded with treatment $\left(\mathrm{T}_{7}\right)$ 50\% Urea, 50\% Vermicompost and 50\% FYM. The shoot length was recorded in $\mathrm{T}_{7}(3.00 \mathrm{~cm})$ followed by treatment $\mathrm{T}_{6}$ $(2.42 \mathrm{~cm})$ in combined given treatment. In individual given treatments the higher shoot length was recorded in $\mathrm{T}_{2}(2.30 \mathrm{~cm})$. The lowest shoot length was recorded in $\mathrm{T}_{0}(2.15 \mathrm{~cm})$ [5]. 


\section{Seedling length $(\mathrm{cm})$}

Among the treatments significantly higher seedling length was recorded in variety G-4 with treatment $\left(\mathrm{T}_{7}\right) \quad 50 \%$ Urea, $50 \%$ Vermicompost and 50\% FYM. The seedling length was recorded in $\mathrm{T}_{7}$ $(5.45 \mathrm{~cm})$ followed by treatment $\mathrm{T}_{6}(4.60 \mathrm{~cm})$ in combined given treatment. In individual given treatments the higher seedling length was recorded in $\mathrm{T}_{2}(4.32 \mathrm{~cm})$. The lowest seedling length was recorded in $\mathrm{T}_{1}(3.15 \mathrm{~cm})$. In variety Suryamukhi the higher seedling length was recorded with treatment $\left(\mathrm{T}_{7}\right) 50 \%$ Urea, 50\% Vermicompost and 50\% FYM. The seedling length was recorded in $T_{7}(5.30 \mathrm{~cm})$ followed by treatment $\mathrm{T}_{6}(4.45 \mathrm{~cm})$ in combined given treatment. In individual given treatments the higher seedling length was recorded in $\mathrm{T}_{2}(4.30$ $\mathrm{cm})$. The lowest seedling length was recorded in $\mathrm{T}_{0}(3.72 \mathrm{~cm})[6]$.

\section{Seedling dry weight $(\mathrm{mg})$}

Among the treatments significantly higher seedling dry weight was recorded in variety G-4 with treatment $\left(\mathrm{T}_{7}\right)$ 50\% Urea, 50\% Vermicompost and 50\% FYM. The seedling dry weight was recorded in $\mathrm{T}_{7}(0.037 \mathrm{mg})$ followed by treatment $\mathrm{T}_{5}(0.030 \mathrm{mg})$ in combined given treatment. In individual given treatments the higher seedling dry weight was recorded in $\mathrm{T}_{2}(0.030 \mathrm{mg})$. The lowest seedling length was recorded in $\mathrm{T}_{1}(0.012 \mathrm{mg})$. In variety Suryamukhi the higher seedling dry weight was recorded with treatment $\left(\mathrm{T}_{7}\right) \quad 50 \%$ Urea, $50 \%$ Vermicompost and 50\% FYM. The seedling dry weight was recorded in $\mathrm{T}_{7}(0.035 \mathrm{mg})$ followed by treatment $\mathrm{T}_{5}(0.030 \mathrm{mg}$.) in combined given treatment [7]. In individual given treatments the higher seedling dry weight was recorded in $\mathrm{T}_{2}(0.030 \mathrm{mg})$. The lowest seedling dry weight was recorded in $\mathrm{T}_{0}(0.017 \mathrm{mg})$.

\section{Seedling vigour index I}

Among the treatments significantly higher vigour index was recorded in variety G-4 with treatment $\left(\mathrm{T}_{7}\right)$ 50\% Urea, $50 \%$ Vermicompost and 50\% FYM. The vigour index was recorded in $\mathrm{T}_{7}$ (539.60) followed by treatment $T_{6}(450.70)$ in combined given treatment. In individual given treatments the higher vigour index was recorded in $\mathrm{T}_{2}$ (415.20). The lowest vigour index was recorded in $\mathrm{T}_{1}$ (365.40). In variety Suryamukhi the higher vigour index was recorded with treatment $\left(\mathrm{T}_{7}\right)$ 50\% Urea, 50\% Vermicompost and 50\% FYM. The vigour index was recorded in $T_{7}(525.30)$ followed by treatment $T_{6}$ (420.40) in combined given treatment. In individual given treatments the higher vigour index was recorded in $\mathrm{T}_{2}$ (406.45). The lowest vigour index was recorded in $\mathrm{T}_{0}$ (333.60) (Table 2).

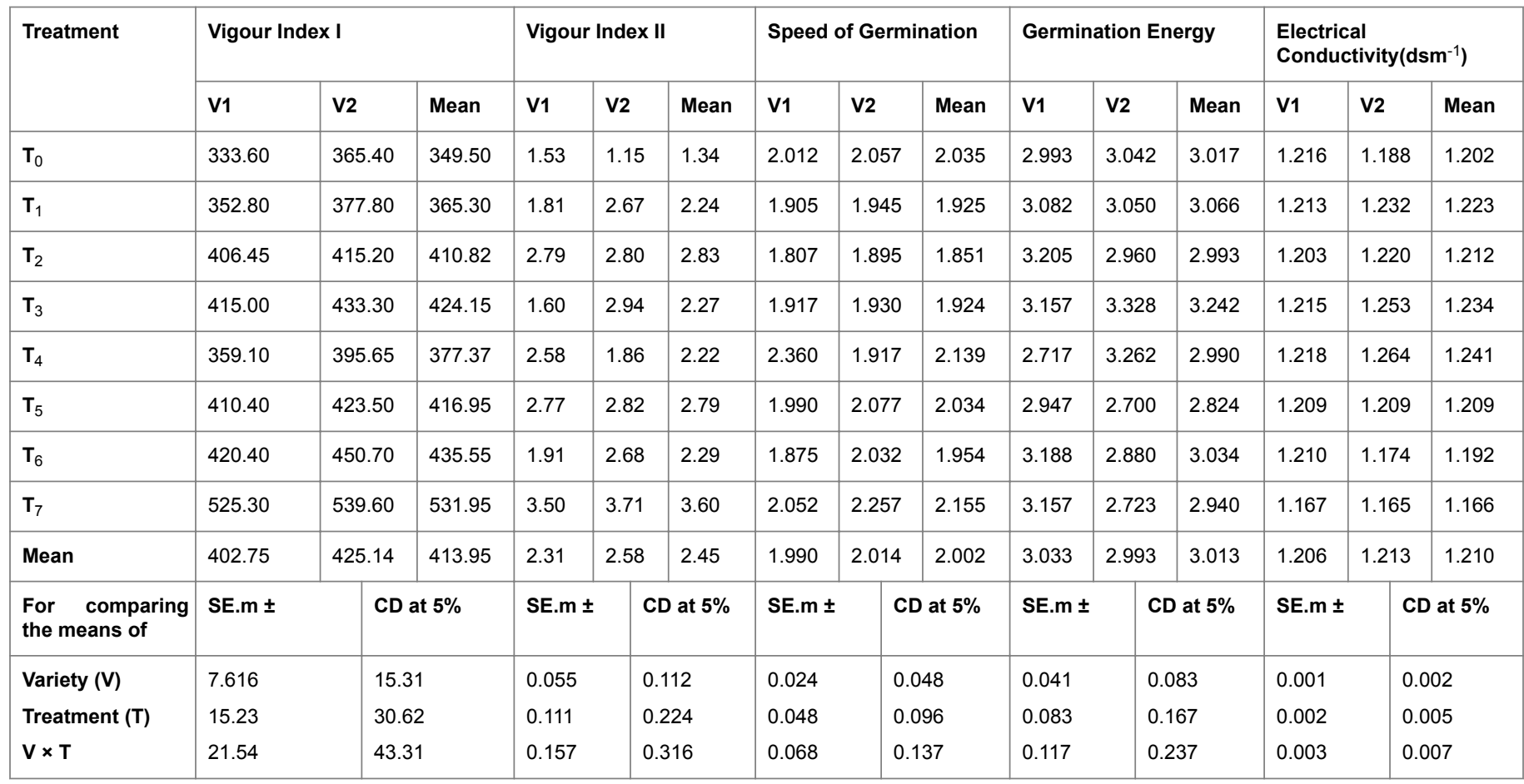

Table 2: Effect of organic and inorganic fertilizer on germination on number of branches at different stages of chilli (Capsicum annum L.).

\section{Seedling vigour index II}

Among the treatments significantly higher vigour index was recorded in variety G-4 with treatment $\left(\mathrm{T}_{7}\right) \quad 50 \%$ Urea, $50 \%$ Vermicompost and 50\% FYM. The vigour index was recorded in $\mathrm{T}_{7}$ (3.710) followed by treatment $\mathrm{T}_{3}(2.94)$ in combined given treatment. In individual given treatments the higher vigour index was recorded in $\mathrm{T}_{2}$ (2.80). The lowest vigour index was recorded in $\mathrm{T}_{1}(1.150)$. In variety Suryamukhi the higher vigour index was recorded with treatment $\left(\mathrm{T}_{7}\right) 50 \%$ Urea, 50\% Vermicompost and 50\% FYM. The vigour index was recorded in $T_{7}$ (3.500) followed by treatment $T_{5}$ (2.77) in combined given treatment. In individual given treatments the higher vigour index was recorded in $\mathrm{T}_{2}$ (2.79). The lowest vigour index was recorded in $\mathrm{T}_{0}$ (1.53).

\section{Speed of germination}

Among the treatments significantly higher speed of germination was recorded in variety G-4 with treatment $\left(\mathrm{T}_{7}\right)$ 50\% Urea, $50 \%$ Vermicompost and 50\% FYM. The speed of germination was recorded 
Citation: Mishra A, Dayal A (2018) Effect of Organic and Inorganic Fertilizers on Seed Quality of Different Varieties of Chilli (Capsicum annum L.). Nat Prod Chem Res 6: 326. doi:10.4172/2329-6836.1000326

Page 4 of 4

in $T_{7}$ (2.257) followed by treatment $T_{5}$ (2.077) in combined given treatment. In individual given treatments the higher speed of germination was recorded in $\mathrm{T}_{1}$ (1.945). The lowest speed of germination was recorded in $\mathrm{T}_{2}$ (1.859). In variety Suryamukhi the higher speed of germination was recorded with treatment $\left(\mathrm{T}_{7}\right) 50 \%$ Urea, 50\% Vermicompost and 50\% FYM. The speed of germination was recorded in $\mathrm{T}_{7}$ (2.052) followed by treatment $\mathrm{T}_{5}$ (1.990) in combined given treatment. In individual given treatments the higher speed of germination were recorded in $\mathrm{T}_{4}$ (2.360). The lowest speed of germination was recorded in $\mathrm{T}_{2}$ (1.807) [8].

\section{Germination energy}

Among the treatments significantly higher germination energy was recorded in variety G-4 with treatment $\left(\mathrm{T}_{6}\right) 50 \%$ Vermicompost and $50 \%$ FYM. The germination energy was recorded in $\mathrm{T}_{6}(2.880)$ followed by treatment $\mathrm{T}_{7}$ (2.723) in combined given treatment. In individual given treatments the higher germination energy was recorded in $\mathrm{T}_{1}$ (3.050). The lowest germination energy was recorded in $\mathrm{T}_{5}$ (2.700). In variety Suryamukhi the higher germination energy was recorded with treatment $\left(\mathrm{T}_{6}\right)$ 50\% Vermicompost and 50\% FYM. The germination energy was recorded in $\mathrm{T}_{6}$ (3.188) followed by treatment $\mathrm{T}_{7}$ (3.157) in combined given treatment. In individual given treatments the higher germination energy were recorded in $\mathrm{T}_{2}$ (3.205). The lowest germination energy was recorded in $\mathrm{T}_{0}$ (2.993).

\section{Electric conductivity $\left(\mathrm{dsm}^{-1}\right)$}

Among the treatments significantly lowest electric conductivity was recorded in variety G-4 with treatment $\left(\mathrm{T}_{7}\right) \quad 50 \%$ Urea, $50 \%$ Vermicompost and 50\% FYM. The electric conductivity was recorded in $\mathrm{T}_{7}$ (1.165) followed by treatment $\mathrm{T}_{6}(1.174)$ in combined given treatment. In individual given treatments the lowest electric conductivity was recorded in $\mathrm{T}_{0}$ (1.188). The higher electric conductivity was recorded in $\mathrm{T}_{4}$ (1.264). In variety Suryamukhi the lowest electric conductivity was recorded with treatment $\left(\mathrm{T}_{7}\right) 50 \%$ Urea, 50\% Vermicompost and 50\% FYM. The electric conductivity was recorded in $T_{7}$ (1.167) followed by treatment $T_{5}$ (1.290) in combined given treatment. In individual given treatments the lowest electric conductivity were recorded in $\mathrm{T}_{2}$ (1.203). The higher electric conductivity was recorded in $\mathrm{T}_{4}(1.218)$.

\section{Conclusion}

On the basis of experiment conducted in laboratory, we found that in eight given treatments $T_{7}$ in combined and $T_{2}$ in individual are better then and $\mathrm{T}_{0}$ lower than others. It is concluded that the effect of organics on seed quality of chilli (Capsicum annum L.) variety's (Suryamukhi and G-4) of chilli (50\% Urea, 50\% Vermicompost and $50 \%$ FYM) in combined and (Vermicompost @ $2.5 \mathrm{t} \mathrm{ha}^{-1}$ ) in individual given treatments showed better results compare to other treatments. If we have implement $T_{7}$ and $T_{2}$ treatments in India, so certainly will be reached optimum position.

\section{References}

1. Patil ID, Babalad HB, Patil RK (2014) Effect of organic nutrient and Biological pest management practices on insect pest and disease dynamics in organic chilli production system. Int J Recent Scient Res 5: 1524-1528.

2. Reddy GC, Venkatachalapathi V, Reddy PD, Hebbar SS (2017) Study of different organic manure combination on growth and yield of chilli (capsicum annuum L.). Plant Archives 17: 472-474.

3. Geetharani P, Parthiban S (2014) Effect of organic manures on growth and seed yield of tomato. Asian J Horticul 9: 281-282.

4. ISTA (1966) International Seed Testing Association. Proc Intern Seed Test Assoc 31: 1-152.

5. ISTA (2006) International Seed Testing Association. International rules for seed testing. Seed Sci Technol, p: 21.

6. Maguire JD (1962) Speed of germination-aid selection and evaluation for seedling emergence and vigour. Crop Sci 2: 176-177.

7. Panse VG (1967) Statistical method for agriculture workers. Indian Council of Agricul Res, p: 381.

8. Warrier PK (1989) Spice in Ayurveda. Indian Spi 26: 21-23. 